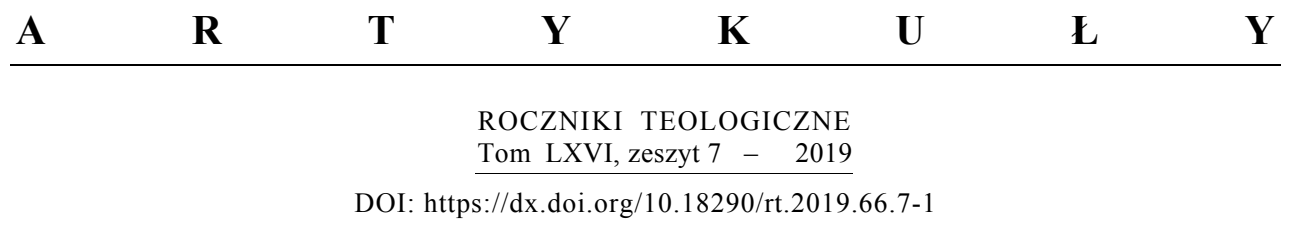

KS. MAREK JAGODZIŃSKI

\title{
KOMUNIJNO-TRYNITARNA POZYCJA DUCHA ŚWIĘTEGO
}

\author{
COMMUNIONAL-TRINITARY POSITION \\ OF THE HOLY SPIRIT
}

\begin{abstract}
A bstract. In the New Testament, you can see the beginnings of Trinitarian pneumatology, which began to develop in the changing context of the cultural world. The view of the Holy Spirit in the perspective of Trinitarian love was of great importance here. The communion dimension also had teaching about Filioque. From the Middle Ages, a process of forgetting the Holy Spirit began in the West and it was only in newer theology that a renaissance in pneumatology was possible thanks to the integration of theological reflection and spiritual experience, in particular, thanks to the new awakening of the Church's sense of unification in a manner of communion that emboldened outstanding theologians to undertake a penetrating search in pneumatology.
\end{abstract}

Key words: pneumatology; Holy Trinity; Communion; Filioque; kenosis.

W procesie tworzenia traktatu o Duchu Świętym istotną rolę odgrywa pneumatologia biblijna, przyjmująca zwykle postać relacji o pneumatologicznej zawartości poszczególnych grup pism Nowego Testamentu ${ }^{1}$, przy czym pojawiały się także zagadnienia dotyczące relacji Ducha Świętego do

Ks. prof. dr hab. MAREK JAGODZIŃSKI - teolog dogmatyk, pracownik Katedry Teologii Prawosławnej w Sekcji Ekumenicznej w Instytucie Nauk Teologicznych na Wydziale Teologii KUL, wykładowca WSD w Radomiu i Instytutu Teologicznego w Radomiu w ramach Papieskiego Wydziału Teologicznego „Bobolanum” w Warszawie, Sekcja Św. Jana Chrzciciela; specjalizuje się w teologii komunikacji i komunii; adres do korespondencji - e-mail: ksemjot@tlen.pl.

${ }^{1}$ Por. np. M.-A. Chevalier, Biblische Pneumatologie, w: Neue Summe Theologie, red. P. Eicher, t. 1: Der lebendige Gott, Freiburg-Basel-Wien: Herder Verlag 1988, s. 341-378. Y. Congar w bardziej usystematyzowanej formie przedstawia Ducha Świętego jako „Tchnienie Słowa” i „Ducha Syna” oraz pisze także o chrystologii pneumatycznej. Por. Systematische Pneumatologie, w: Neue Summe Theologie, red. P. Eicher, t. 1: Der lebendige Gott, s. 393-399. 
pozostałych Osób Boskich. W kwestii istotnego dla chrystologii pytania o wzajemne odniesienie między Synem a Duchem Świętym, jak i o przenikającą się wspólność działania zbawczego Obydwu, można zauważyć np. u św. Jana początki pneumatologii trynitarnej². Podobnie jak św. Paweł, Jan nie przedstawia perspektywy spekulatywnej tradycji biblijnej, lecz perspektywę historyczną i praktyczną. W mowach pożegnalnych ujawniają się nie Osoby, lecz ich funkcje - jako że pojęcie „osoby” jest obce tak Nowemu, jak i Staremu Testamentowi, a w myśli biblijnej to funkcja określa tożsamość danej postaci. Potrzebna więc była zmiana kontekstu świata kulturowego, żeby mogła pojawić się refleksja trynitarna ${ }^{3}$.

\section{DUCH ŚWIĘTY W PERSPEKTYWIE MIŁOŚCI TRYNITARNEJ}

Podkreślając transcendencję miłości Bożej, L. Bouyer pisał, że istotą Ojca jest osobowa agape, i dołączył istotny komentarz, że owa agape jest Osobą w całym znaczeniu tego słowa, najważniejszą i jedyną w sobie samej i przez siebie samą, gdyż jest ofiarowywaniem siebie w Synu. Z tej przyczyny cała znajduje się w Ojcu i przelewa się w Syna jako jedynego i absolutnie umiłowanego oraz miłującego wzajemnie, razem z Duchem Świętym jako miłością jednocześnie otrzymywaną i oddawaną. Ta miłość jest w Ojcu, pierwszym i podstawowym Źródle miłości. „Nie można więc powiedzieć [...] że Duch Święty jest w Bogu miłością osobową, ponieważ miłość, będąca życiem Boga, która jest Ojcem w samym jego ojcostwie, która jest Synem jako umiłowanym i miłującym wzajemnie, dopełnia się w Duchu Ojca, będącym właśnie Duchem przybrania za Synów, spoczywającym na Synu jako Duch dobrowolnej wzajemności, przez którego ten sam jest zarazem w najwyższym stopniu miłujący i miłowany. $W$ tym znaczeniu Duch, jak wskazuje jego nazwa, jest tchnieniem życia Bożego lub - inaczej -

\footnotetext{
${ }^{2}$ Zob. zbiór świadectw Pisma Świętego na temat zjednoczenia Słowa i Ducha w Y. CongAR, Stowo i Tchnienie, tłum. M. Jagielski, Kraków: Wydawnictwo WAM 2018, s. 34-39.

${ }^{3}$ Por. Chevalier, Biblische Pneumatologie, s. 370. „Die bekannte Aussage «Gott ist Geist» (Joh 4,24) darf man nicht aus dem Kontext (Joh 4,19-26) herausreißen. Jedenfalls ist das keine abstrakte Definition des Wesens Gottes. Gegenüber dem religiösen Suchen der Welt - wo ist denn Gott, daß man ihn anbeten kann - bekräftigt Jesus in echt johanneischem Stil, daß sich der Vater «jetzt», das heißt nach dem Werk des Sohnes, hier unten als Gott «von oben» zu erkennen gibt. Der Geist ist die Weise, in der Gott selbst unter die Menschen tritt, in der er geheimnisvoll anwesend ist wie das Wehen des Windes; die Unterredung mit Nikodemus (vgl. Joh 3,5-15) zeigt das deutlich. Das ist keine metaphysische, sondern eher eine dramatische Darstellung..." (tamże, s. 370 n.).
} 
jest On jakby sercem Bóstwa, sercem Ojca, które jest jednocześnie sercem Syna, darem udzielającym życia, pozwalającym miłować miłością, jaką się jest miłowanym. Życie Boga jest zatem doskonałe w sobie samym jako życie miłości, [...] która, [...] musi istnieć między dwiema Osobami, a która, pomiędzy tych dwóch stanowiących jedno - Ojca i Syna, nie mówimy, że wkracza jako trzecia Osoba, co byłoby największym nonsensem, ale - że jest pieczęcią ich jedynej bliskości i niewyczerpanym źródłem ich nieskończoności. Dlatego ów Duch, w którym miłość Boża, miłość, która jest Bogiem, objawia się w swej doskonałości, w swej świętości ponad wszelkimi definicjami, ponieważ ponad wszelkimi ograniczeniami - jest również Tym, w którym objawia się absolutna wolność Boga, nie przeciwko jedynej konieczności tego jedynego koniecznego bytu, ale jako właśnie konieczność jego istnienia, będącego istnieniem Jednego poza jednością i poza wielością"4

\section{KOMUNIJNY WYMIAR NAUCZANIA O FILIOQUE}

Symbol Quicumque zawiera naukę o niepodzielnej jedności Ojca, Syna i Ducha Świętego, wyraźne określenie Bóstwa wszystkich Osób Boskich i wreszcie Filioque w umiarkowanym sformułowaniu, które pojawiło się wraz z pytaniem o pochodzenie Ducha Świętego i Jego relację do Syna.

\footnotetext{
${ }^{4}$ L. BouYer, Duch Święty Pocieszyciel. Duch Święty i życie w łasce, tłum. A. Liduchowska, Kraków: Wydawnictwo „M” 2000, s. 535 n. Autor uzupełnia te wypowiedź myślą o kenozie Ducha Świętego, w której On objawia się także stworzeniu: „Duch jest tą osobowością Bożą, która objawia się jako miłość u swego kresu, czyniąca jednym umiłowanego i miłującego, gdzie umiłowany jest nim właśnie dzięki swej wzajemności, tak jak osoba Boga Ojca, widzialnego tylko w Synu, w którym objawia się przez Ducha, jest miłością w swoim jedynym, przedwiecznym źródle, istotowym lub «nadistotowym», jak powiedziałby Pseudo-Dionizy. Tym bardziej Duch Święty powinien więc być Tym, w kim Mądrość stworzenia, w swoim dobrowolnym odróżnieniu od stwórczego Słowa, jest powołana do bycia ze Słowem jedno, w miłości oblubieńczej, która przenosi ją na płaszczyznę miłości synowskiej, pozwalając jej spoczywać razem z Synem, przez Ducha, w łonie Ojca. W tym celu zaczęła ona w tym samym Duchu być Mądrością macierzyńską wobec każdego pojedynczego stworzenia, a jeszcze bardziej - dla wszystkich stworzeń, zgromadzonych w jedno przez Stwórcę i w Nim. W rezultacie pomiędzy nimi, w miejscu ich spotkania, krzyż, na którym Stwórca w swej miłości, w owej miłości będącej Nim samym czyni się jednym ze stworzeniem, w jego dwakroć nieskończonym oddaleniu od Boga, jeśli można tak powiedzieć, mając na myśli stworzenie świata w porządku ograniczonym oraz jego upadek - ów krzyż jest najwymowniejszym znakiem Ducha dla wiary. Podobnie zmartwychwstanie Ukrzyżowanego, kontynuowane przez powszechne zmartwychwstanie w dniu Paruzji, stanie się chwałą przygotowaną przez ową kenozę Ducha Świętego, chwałą, w której wiara zanika, ponieważ staje się widzeniem" (tamże, s. 545 n.). Por. R. LAUREnTin, Nieznany Duch Święty. Odkrywanie Jego doświadczenia i Jego Osoby, tłum. M. Tarnowska, Kraków: Wydawnictwo Znak 1998, s. 369-373.
} 
Grecy i łacinnicy najpierw zgodnie mówili o pochodzeniu Ducha Świętego od Ojca przez Syna. Chcieli pokazać, że jedynym źródłem Bóstwa jest tylko Ojciec, Duch natomiast, zgodnie z danymi Pisma Świętego, jest pośredniczony przez Syna, to znaczy wychodzi od Ojca i przekazywany jest przez Syna światu. Oprócz tego teologowie Wschodu i Zachodu nauczali także o pochodzeniu Ducha Świętego od Ojca i Syna. Św. Cyryl Aleksandryjski uważał, że Duch był „,własnością” Syna oraz pochodził „od Obu”, ale nie miał na myśli ścisłej relacji Syna i Ducha Świętego, lecz Boską godność bytową Ducha Świętego, a także chciał obronić przed arianami Jego równość natury $\mathrm{z}$ Synem. Filioque (w przedmiotowym, niekoniecznie dosłownym znaczeniu) spełniało zatem przez długi czas różnorodne funkcje teologiczne i nieraz było odbierane jako wręcz fałszywe lub krępujące ${ }^{5}$.

Problem zainicjowany został przez trynitarną teologię św. Augustyna. Ponieważ pojmował on Ducha Świętego jako to, co wspólne między Ojcem i Synem - jako Ich obustronny Dar - źródła Jego pochodzenia trzeba było szukać u Nich obydwu. Augustyn odważniej od teologów wschodnich wyciągał wnioski dotyczące wewnątrztrynitarnego życia Boga. Jego trynitarny model myślowy pozwala jednak założyć raczej cyrkulacyjną niż linearną dynamikę, która nie zmierza, jak myśl wschodnia, od Ojca do Syna i potem do Ducha Świętego, lecz wychodzi od Ojca w Duchu do Syna i odwrotnie. Pierwotnie wyznanie wiary mówiło o pochodzeniu Ducha Świętego ,od Ojca”. W łacińskim przekładzie symbolu na obszarze frankońskim już od VIII Synodu w Toledo (653 r.) występowało wyrażenie Filioque ${ }^{6}$. Św. Maksym Wyznawca i św. Jan Damasceński uznawali troskę Zachodu o jedność i równość istoty Boga, której wyrazem było Filioque i którą sami podzielali, ale obstawali również za zachowaniem dotychczasowej nauki. Podkreślali absolutną pierwotność Ojca i jedyne arche oraz samoistny status trzech Hipostaz, jednakże nie zaprzeczali uczestnictwu Syna w pośrednictwie Ducha Świętego - zwłaszcza Damasceńczyk uważał, że powinno się Go nawet nazywać Duchem Syna. Zerwanie kościelnej wspólnoty między Wschodem i Zachodem spowodowało, że kwestia Filioque stała się przedmiotem nieporozumień ${ }^{7}$. Lacinnicy starali się odeprzeć zarzut, jakoby

\footnotetext{
${ }^{5}$ Por. B. Stubenrauch, Pneumatologia - traktat o Duchu Świętym, (Podręcznik Teologii Dogmatycznej, red. W. Beinert, traktat VIII), thum. P. Lisak, Kraków: Wydawnictwo „M” 1999, s. 152-155; Y. CONGAR, Wierzę w Ducha Świętego. Rzeka życia ptynie na Wschodzie i na Zachodzie (Ap 22,1), tłum. L. Rutowska, t. III, Warszawa: Wydawnictwo Księży Marianów 1996, s. 70-78.

${ }^{6}$ Por. Congar, Wierze w Ducha Świętego, s. 157-160.

${ }^{7} \mathrm{Na}$ temat pochodzenia Ducha Świętego według Tradycji wschodniej zob. P. LISZKA, Duch Święty, który od Ojca (i Syna) pochodzi, Wrocław: Papieski Wydział Teologiczny 2000, s. 91-137.
} 
przez Filioque postulowane były dwie pierwotne zasady pochodzenia Ducha Świętego zamiast jednej. II Sobór Lyoński uczył, że Duch Święty wiecznie pochodzi od Ojca i Syna nie jako od dwóch zasad, lecz jak od jednej zasady. Nie doszło jednak do zjednoczenia. Również osiągnięty na Soborze Florenckim sukces nie trwał długo, chociaż jego nauka wychodziła naprzeciw myśli greckiej poprzez odsłonięcie dokładnego sensu teologicznej treści wypowiedzi „od Ojca przez Syna” oraz „od Ojca i Syna” i torowała droge do pojednania ${ }^{8}$.

\section{PNEUMATOLOGICZNY WKŁAD MYŚLI ŚREDNIOWIECZNEJ}

Przejście do wczesnego średniowiecza charakteryzuje się przejęciem dorobku minionych epok i nie prezentuje oryginalnej myśli pneumatologicznej. Tylko nieliczne wybitne umysły zajęły się kontynuacją przekazanej Tradycji. Właśnie wtedy rozpoczął się proces pewnego zapomnienia Ducha Świętego. Scholastyczna nauka o Bogu miała na myśli nie tyle Osoby i Ich ontyczną równość, co raczej istnienie jedynego Bóstwa (una deitas). Niezależnie jednak od tego, czy pochodzenie Ducha Świętego wyprowadzało się na sposób psychologiczny z jedności rozumu, poznania i chcenia czy też z przekonania, że w Duchu Świętym spotyka się wzajemna miłość Ojca i Syna - Duch Święty pozostawał probierzem wewnątrzboskiej wymiany miłości ${ }^{9}$.

\footnotetext{
${ }^{8}$ Por. W. KASPER, Bóg Jezusa Chrystusa, thum. J. Tyrawa, Wrocław: TUM Wydawnictwo Wrocławskiej Księgarni Archidiecezjalnej 1996, s. 267-276; Stubenrauch, Pneumatologia, s. 155-159; Laurentin, Nieznany Duch Święty, s. 357 n., 362-364. Na temat współczesnej pneumatologii wschodniej zob. ConGAR, Wierzę w Ducha Świętego, s. 95-102, 207-251.

${ }^{9}$ Por. Stubenrauch, Pneumatologia, s. 159-162. L. Bouyer odnotował, że Bułgakow „w pewnym sensie uznając augustyńskie utożsamienie Ducha Świętego i Bożej miłości, jednocześnie przeciwstawia się trynitologii zachodniej biorącej początek od św. Augustyna z jej «pochodzeniem» Syna drogą rozumu i pochodzeniem Ducha drogą woli. Twierdzi on, że miłość, a w każdym razie miłość, o której mowa w tym przypadku, jest czymś zupełnie innym niż sprawą woli. Trudno o celniejsze spostrzeżenie. Dodajmy, że mimo równoczesnego odnoszenia do drugiej Osoby Boskiej terminów «Syn» i «Logos» - Boży «rozum», jego «samoświadomość» nie mogą być stawiane na równi ze zrodzeniem, które czyni Boga przede wszystkim Ojcem" (s. 529). Chodzi tu o uświadomienie sobie w pełni i spójnie całej oryginalności chrześcijańskiego pojęcia miłości: „miłość otrzymująca nazwę agape jest czymś zupełnie innym niż pragnienie. Miłość Boga w Biblii, zwłaszcza zaś w Ewangelii, jest rzeczywiście darem, darem z wszystkiego, co się posiada, a nawet z wszystkiego, czym się jest, darem nie wymagającym żadnej wzajemności w ścisłym znaczeniu tego słowa, darem niezasłużonym i «niezasługiwalnym», darem, który w
} 
Widać to już w nauce św. Anzelma z Canterbury: w Duchu Świętym Ojciec kocha Syna i odwrotnie. Miłość ta jednakże jest identyczna z jedną istotą Boga. Dlatego Duch Święty pochodzi od Ojca i od Syna, którzy stanowią jedność, a zatem stanowią dla Ducha Świętego samoistną zasadę jednego Bóstwa ${ }^{10}$. Również św. Tomasz z Akwinu uczył, że ponieważ odrębność Boskich Osób wypływa wyłącznie z innych relacji, nie dałoby się stwierdzić różnicy między Duchem Świętym i Synem, jeśli Duch Święty nie pochodziłby również od Syna ${ }^{11}$. Ryszard ze Świętego Wiktora w nowy sposób powiązał trójosobowe istnienie Boga z rzeczywistością „miłości”. Ponieważ miłość doskonała działa w Bogu na zasadzie dialogu, od jednej „Osoby” zmierza do drugiej, od Miłującego do Miłowanego. Nie można poprzestać na dwoistości, bo wtedy jeden zamykałby się w drugim, a następstwem byłaby relacja ,egoizmu we dwóch”. Z tego również powodu Ojciec i Syn zwracają się ku Trzeciemu - Ryszard nazywał Go Condilectus, „Współumiłowanym”, ponieważ probierzem doskonałej miłości jest chęć dalszego jej przekazywania. Z tego określenia Ducha Świętego jako Współumiłowanego, który całkowicie pochodzi ze wzajemnej miłości Ojca i Syna oraz poniekąd sam daje jej początek i kieruje ją do Obu, wyprowadza się samoistność Ducha Świętego: On jest Darem oraz Płomieniem. W Nim Ojciec i Syn dają się sobie nawzajem; w Nim także trynitarna miłość otwiera się na stworzenie i przechodzi na stworzenie. Wprawdzie stworzenie nie stanowi odpowiedniego partnera dla wewnątrzboskiej miłości, z pewnością jednak jest adresatem Jego łaskawej miłości jako Stwórcy ${ }^{12}$. Drogę rozumowania Ryszarda ze Świętego Wiktora kontynuowali Wilhelm z Auxerre oraz św. Bonawentura ${ }^{13}$. Od Pseudo-Dionizego Areopagity scholastyka przejęła wyobrażenie, że dobroć z konieczności rozlewa się na zewnątrz: Bonum diffusivum sui. Wyobrażenie to u średniowiecznych teologów przybiera rys wewnątrztrynitarny, przy czym Duch Święty traktowany jest jako owoc ekstatycznej, przekraczającej siebie dobroci Ojca i Syna ${ }^{14}$.

\footnotetext{
konsekwencji nigdzie nie objawi się tak wyraźnie, jak w przebaczeniu, choć nie sprowadza się on do przebaczenia, ale dzięki niesłychanej, niepojętej hojności Bożej, przerasta zarówno miłosierdzie, nawet najwznioślejsze, jak i najbardziej wymagającą sprawiedliwość" (tamże, s. 530). Por. CONGAR, Wierzę w Ducha Świętego, s. 134-142.

${ }^{10}$ Por. Congar, Wierze w Ducha Świętego, s. 121-127.

${ }^{11}$ Por. Stubenrauch, Pneumatologia, s. 162 n.; Congar, Wierzę w Ducha Świętego, s. $143-155$.

${ }^{12}$ Por. Congar, Wierzę w Ducha Świętego, s. 128-133.

${ }^{13}$ Por. tamże, s. 134-142.

${ }^{14}$ Por. Stubenrauch, Pneumatologia, s. 163-165.
} 


\section{KOMUNIJNE WYMIARY \\ WSPÓŁCZESNEJ MYŚLI PNEUMATOLOGICZNEJ}

Pneumatologia przeżyła w nowszej teologii renesans możliwy dzięki zintegrowaniu refleksji teologicznej i doświadczenia duchowego, w szczególności dzięki nowemu obudzeniu się kościelnego poczucia zjednoczenia na sposób ,my”, które ośmieliło wybitnych teologów do rozważań pneumatologicznych: Y. Congara, L. Bouyera, H.U. von Balthasara, K. Rahnera i H. Mühlena. Wedle H. Mühlena szczególną rolę odgrywa doświadczenie „My” w Duchu Świętym. Mühlen określa Ducha Świętego wewnątrztrynitarnie jako Boskie „My”, jako zażyłą więź Ojca i Syna ,w Osobie”, jako „My w Osobie”. Analogicznie do tego wewnątrztrynitarnego określenia Ducha Świętego wyjaśnia Jego funkcję historiozbawczą; jest On jakby Boskim ,,byciem-poza-sobą”, poniekąd samym Bogiem jakby ,wychodzącym z siebie - Duchem Świętym pojętym jako Boskie samooddawanie się"15.

Jako Dar Duch Święty pochodzi od Ojca, podczas gdy Ojciec przekazuje Synowi wszystko, co sam , posiada" - siebie samego w miłości. Bogactwem Boga jest właśnie Duch Święty. On wypływa z doskonałego oddania się podmiotowo-osobowego Ojca, który nic nie zatrzymuje dla siebie, a przecież jako „Ojciec” ofiaruje Synowi i pozostaje „Ojcem”. Oznacza to, że również Syn, któremu wszystko zostało przekazane od Ojca, bez reszty ofiaruje się Ojcu. Jako podmiot pozostaje On jednakże ofiarowany Ojcu jako „Syn”. W ten sposób rozjaśnia się misterium Ducha Świętego: On jest Darem nie jak Ojciec i Syn, będący dla siebie nawzajem zarazem Dawcą i Darem, lecz jest czystym Darem. Duch Święty jest Darem, zamieszkując całkowicie w Ojcu i całkowicie w Synu oraz umożliwiając zaistnienie między Nimi relacji i odróżniając Ich od siebie. On jest również Darem sprawiającym w niepowtarzalny i niezastępowalny sposób boskie bycie Bogiem, a przez to umożliwiającym udzielanie się Boga w sobie samym i na zewnątrz. Skoro Ojciec całkowicie ofiaruje się Synowi, a Syn czyni to samo w odniesieniu do Ojca, a skoro Obaj w tej relacji nie zatracają się wzajemnie, ponieważ jako podmioty pozostają dla siebie nawzajem Dawcami, czysty Dar nie może być zatem jedynie reprodukcją Ich samych, stanowi wobec Nich raczej coś Innego, coś ,Trzeciego”. On jest Bogiem-Duchem Świętym, który jako

\footnotetext{
${ }^{15}$ Por. tamże, s. 215 n.; LAUREnTin, Nieznany Duch Święty, s. 360-362; Y. CONGAR, Wierze w Ducha Świętego. Duch Święty w ekonomii Objawienia $i$ doświadczenie Ducha, tłum. A. Paygert, t. I, Warszawa: Wydawnictwo Księży Marianów 1995, s. 64-67.
} 
Osoba jednoczy w sobie Ojca i Syna, ale jako podmiot jest zarazem tym Darem i prócz tego odróżnia się od Ojca i Syna ${ }^{16}$.

W nawiązaniu do myśli Ryszarda ze Świętego Wiktora ukazuje się fenomenologia doskonałej miłości. Ojciec jest miłością obdarowująca, Syn jest odbierającym i obdarowującym miłością, Duch Święty jest czystą miłością odbierającą ${ }^{17}$, ale są Oni tą samą miłością w trzech rytmach ${ }^{18}$. „Duch Święty jest $w$ rytmice miłości $z$ jednej strony czystym otrzymywaniem, ponieważ jest darem Ojca i Syna (w inny sposób) oraz miłosną odpowiedzią w chwale i uwielbieniu. $Z$ drugiej zaś strony jest węzłem miłości między Ojcem i Synem, który sprawia ich jedność i jedność bycia. Jest «Trzecim» (według Ryszarda ze św. Wiktora), który łączy w ogniu pozbawionej siebie miłości niepojęte bycie innym Ojca i Syna jako Ich «jedność w przeciwstawieniu», jako «uprzedmiotowienie ich podmiotowości», przez co występuje przeciwko możliwości Ich stopienia lub rozejścia się oraz nakierowuje Ich na siebie wzajemnie. Tak Duch Święty przez to, że jest darem Ojca dla Syna i Syna dla Ojca, potwierdza w ten sposób tożsamość dających tożsamość w różnicy Ojca i Syna, a przez to tożsamość w różnicy boskiej Komunii miłości. W podwójnym charakterze węzła miłości Ojca i Syna oraz owocu tej miłości jako Trzeci gwarant tej miłości, Duch Święty nie jest jednak żadną dualnością. Ten podwójny charakter to dwa aspekty tej samej treści, w której wyraża boskie «My» miłości. Duch Święty jest Osobą, w której Communio boskiej miłości znajduje pełny kształt, a nawet więcej w niej w wyjściu «ponad siebie» dokonuje się «rozerwanie» Ojca i Syna. W nim uchwytna się staje osobowa całość boskiego życia"19.

\footnotetext{
${ }^{16}$ Por. Stubenrauch, Pneumatologia, s. 227 n. Czy zachowana zostaje monarchia Ojca, a przez to świadectwo biblijne? Ojciec nigdy nie stanie się Synem, a Syn nigdy Ojcem. Duch Święty również nie wchodzi na sposób Syna w relację Dawca-Dar wobec Ojca. Na tej zasadzie Ojciec przez dawanie samego siebie rodzi Syna, a nie drugiego Ojca. Również i Syn nie odzwierciedla siebie samego w Ojcu, lecz traktuje Ojca jako stałego partnera dialogu. Wreszcie Duch Święty nie „składa się” z Ojca i Syna - w takim przypadku byłby nie Duchem, lecz swego rodzaju „Ojco-Synem” - lecz pochodzi jako Dar. Oznacza to, że urzeczywistnia On Boga w formie czystego daru. Ojciec jednak pozostaje principium non de principio - początkiem bez początku. W przeciwnym razie Jego podmiotowość jako Ojca zostałaby zredukowana do abstrakcyjnej zasady, którą można by wedle upodobania zestawiać z imionami Syna lub Ducha Świętego albo też z jakąś inną metaforą, w konsekwencji zaś naruszona zostałaby istota dogmatu o Trójcy Świętej. Por. tamże, s. 228 n.; LAURENTIN, Nieznany Duch Święty, s. 378-385.

${ }^{17}$ Por. G. Greshake, Trójjedyny Bóg. Teologia trynitarna, thum. J. Tyrawa, Wrocław: Wydawnictwo TUM Wrocławskiej Księgarni Archidiecezjalnej 2009, s. 184 n.

${ }^{18}$ Por. LAUREnTin, Nieznany Duch Święty, s. 377 n.

${ }^{19}$ M. JAGODZIŃSKI, Trialogiczno-komunijna koncepcja trynitologii, „Studia Diecezji Radomskiej” 10 (2010/2011), s. 70. Por. G. Greshake, Trójjedyny Bóg, s. 185n; TEnŻE, Wierzę w Boga
} 
H.U. von Balthasar uważa, że wzajemna wymiana istoty między Ojcem i Synem prowadzi do dynamicznego zjednoczenia w Duchu Świętym. U korzeni tego połączenia spoczywa kenotyczne oddanie siebie. Balthasar podkreśla wydarzeniowy charakter tego procesu. Istotą miłości Ojca i Syna jest Ich wzajemne „zderzanie z sobą" w Duchu Świętym, w którym uwieczniona zostaje konkretyzacja Bożej istoty. To On sprawia wytrwałą „wymianę” wzajemnego bycia w sobie Ojca i Syna. Dynamika Bożej miłości wyraża się właśnie w tym, że istota Boża posiada w odniesieniu do każdej Osoby właściwość „coraz więcej”. Osoba Ducha Świętego przyczynia się do nieograniczonego przenikania się Osób w Bogu. On jest źródłem energii wzajemnego obdarowywania się Ojca i Syna, uosobieniem Ich wzajemnego oddania się. Dramat dystansu między Ojcem i Synem znajduje swoje rozwiązanie w Duchu Świętym. Posiłkując się paradoksalną myślą Adrienne von Speyr, Balthasar twierdzi, że w Trzeciej Osobie Bożej absolutne rozróżnienie między Ojcem i Synem staje się coraz większą miłością. Tchnienie Ducha jest płodnym spotkaniem darowującej się i przyjmującej miłości, która jakby opuszcza siebie samą, by we wspólnym tchnieniu miłości wydać Ducha miłości. Natomiast w ekonomii zbawczej Duch Święty wyraża dynamicznie „narastającą” jedność jako czysty dystans ${ }^{20}$.

Balthasar podkreśla, że w ukazaniu się istotowego zjednoczenia Ojca i Syna odbierają Oni swoją jedność ,jako hipostatyczną istotę miłości”. Duch Święty stanowi konkretną rzeczywistość odniesienia miłości Ojca i Syna, stając się „podmiotowym wcieleniem wzajemnej miłości Ojca i Syna”, czymś więcej niż tylko „wzajemnym nachyleniem” Ojca i Syna, owocem Ich miłości - jest Darem. On sprawia dający początek całej rzeczywistości czyn miłości Ojca oddającego całą swoją istotę Synowi, nie zostaje w niczym umniejszony i pozostaje pierwszym, koniecznym aktem Boskiego wyjścia „na zewnątrz”. Miłość Ojca i Syna zamyka się w Osobie Ducha Świętego w całość „niestanowiącą zagrożenia dla ich osobowych właściwości”, i to tym bardziej, że Duch nie pragnie być „kimś” dla siebie, lecz tylko czystym oznajmieniem miłości pomiędzy Ojcem i Synem ${ }^{21}$.

Balthasar pojmuje Ducha Świętego jako trynitarną dwupostaciowość: najwyższą jedność Ojca i Syna oraz oddzielony od Nich, obiektywny, oso-

trójjedynego. Klucz do zrozumienia Trójcy Świętej, tłum. W. Szymona, Kraków: Wydawnictwo Znak 2001, s. 35.

${ }^{20}$ Por. I. BoKWA, Trynitarno-chrystologiczna interpretacja eschatologii w ujęciu Hansa Ursa von Balthasara, Radom: Radomskie Wydawnictwo Diezezjalne AVE 1998, s. 105 n.

${ }^{21}$ Por. tamże, s. 106. 
bowy „owoc” Ich miłości, Ich odwiecznego rodzenia, „wynik” tej miłości i jej świadectwo. Trzecia Osoba Boska istnieje wiecznie jako samoistna płodność Bożej miłości, jedność niewytłumaczalnej miłości Ojca i Syna. Istota Bożej miłości „narzuca” troistość w Bogu - tchnienie Ducha Świętego stanowi „proces” po Bożemu „konieczny”, ale absolutnie wolny: pochodzący z niego Duch Święty jest wyrazem jedynej w swoim rodzaju wolności Boga. Duch Boży jest tożsamy ze sobą i z istotą Boga - jest Bogiem i jako Osoba jest „połączonym oddechem Ojca i Syna”. Relację między Ojcem i Synem Balthasar opisuje jako bogactwo, podarunek, jedność, wspólnotę miłości. Duch Boży zawiera w sobie całą istotę Boga jako miłości, jest „miłością jako taką i absolutną", wylaną całością bytu jako miłości. Duch miłości jest dla Balthasara „istotą Boga”, który jest jeden dzięki scalającej mocy Ducha miłości, ,jedności nieprzewyższalnej miłości”. Duch Święty stanowi uosobienie, „prosopon” Boskości, która w swej istocie jest czystym wydaniem siebie samej. Jest „ukoronowaniem” narastającej Bożej miłości - Balthasar mówi o „płodności miłości”. To właśnie w mocy Ducha Świętego Bóg „osiąga" nieustannie swoją ostateczną pełnię eschatologiczną ${ }^{22}$.

Prezentacja Boga jako jednej i jedynej, darowującej siebie bez żadnych zastrzeżeń miłości kryje w sobie określony cel, którym jest analogia między strukturą absolutnej miłości Boga a osobowym spotkaniem międzyludzkim. Analogia ta jest obustronna. W teologicznej drodze „odgórnej” oznacza to pojmowanie trynitarnej rzeczywistości Boga jako warunku umożliwiającego zaistnienie miłości między ludźmi, ale analogia ma charakter pomocniczy, a głównym celem Balthasara pozostaje pojęciowo-obrazowe przybliżenie trynitarnej istoty Boga $^{23}$. Będąc miłością Ojca i Syna oraz więzią ich jedności, Duch Święty jest Ich wiekuistą komunikacją, a zatem Ich komunią ${ }^{24}$. „Duch jest komunią Miłującego i Umiłowanego, gwarantującym też komunię Miłującego ze swoimi stworzeniami i z dziejami ich cierpienia, nie z pominięciem Umiłowanego, ale właśnie w Nim i dzięki Niemu. [...] Zróżnicowanie Ojca i Syna zostało przyjęte w najwznioślejszej jedności miłości, pochodzącej od Ojca; a ta miłość, spoczywając na Synu i odbijając się w Nim, stale powraca do swego początku bez początku: Duch jest więzią wiecznej miłości. Dlatego Ojciec pozostaje początkiem, Syn przejawem, Duch Ich osobową więzią w ruchu Boskiej wieczności" 25 .

\footnotetext{
${ }^{22}$ Por. tamże, s. 106 n.

${ }^{23}$ Por. tamże, s. 107.

${ }^{24}$ Por. Laurentin, Nieznany Duch Święty, s. 319 n.

${ }^{25}$ B. FORTE, Istota chrześcijaństwa, thum. K. Kozak, Lublin: Wydawnictwo KUL 2007, s. 99.
} 
Dzieje Syna i Ojca oraz krzyż są również dziejami Ducha Świętego, którego szczytowym aktem wydania jest żertwa ofiarna na krzyżu (J 19,30). Ukrzyżowany wydał Ojcu Ducha, którego Ojciec Mu dał, a którego w pełni otrzyma w dniu zmartwychwstania. W dniu wydania samego siebie przez Syna i Syna przez Ojca na śmierć Duch zostaje wydany przez Syna swemu Ojcu. Jest to godzina „śmierci w Bogu”, opuszczenia Syna przez Ojca w Ich największej komunii miłości, wydarzenie, które dopełnia się w wydaniu Ducha Świętego Ojcu i umożliwia szczytowe wyjście Syna w inność świata. Bez wydania Ducha Świętego krzyż nie objawiłby się w całej swej głębi wydarzenia trynitarnego i zbawczego. Gdyby Duch nie pozwolił się „wydać” w ciszy śmierci, godzina ciemności mogłaby być źle zrozumiana - nie jako akt w Bogu, jako wydarzenie historii miłości nieśmiertelnego Boga. W godzinie krzyża także i Duch Święty tworzy historię w Bogu, ponieważ wydany Ojcu gwarantuje inność Syna od Niego w solidarności z grzesznikami, chociaż pozostając $\mathrm{w}$ nieskończonej komunii wyrażonej w ofiarnym posłuszeństwie Ukrzyżowanego. „Krzyż, jako historia Syna, Ojca i Ducha, jest trynitarną historią Boga"26.

\section{BIBLIOGRAFIA}

BoKWA Ignacy: Trynitarno-chrystologiczna interpretacja eschatologii w ujęciu Hansa Ursa von Balthasara, Radom: Radomskie Wydawnictwo Diezezjalne AVE 1998.

BouYer Louis: Duch Święty Pocieszyciel. Duch Święty i życie w łasce, tłum. Alina Liduchowska, Kraków: Wydawnictwo „M” 2000.

Chevalier Max-Alain: Biblische Pneumatologie, w: Neue Summe Theologie, red. Peter Eicher, t. 1: Der lebendige Gott, Freiburg-Basel-Wien: Herder Verlag 1988.

Congar Yves: Słowo i Tchnienie, Słowo i Tchnienie, tłum. Mariusz Jagielski, Kraków: Wydawnictwo WAM 2018

Congar Yves: Systematische Pneumatologie, w: Neue Summe Theologie, red. Peter Eicher, t. 1: Der lebendige Gott, Freiburg-Basel-Wien: Herder Verlag 1988, s. 379-406.

Congar Yves: Wierzę w Ducha Świętego. Duch Święty w ekonomii Objawienia i doświadczenie Ducha, thum Adam Paygert, t. I, Warszawa: Wydawnictwo Księży Marianów 1995.

Congar Yves: Wierzę w Ducha Świętego. Rzeka życia płynie na Wschodzie i na Zachodzie (Ap 22,1), tłum. Lucyna Rutowska, t. III, Warszawa: Wydawnictwo Księży Marianów 1996.

FORTE Bruno, Istota chrześcijaństwa, tłum. Krystyna Kozak, Lublin: Wydawnictwo KUL 2007.

Greshake Gisbert: Trójjedyny Bóg. Teologia trynitarna, thum. Jan Tyrawa, Wrocław: Wydawnictwo TUM Wrocławskiej Księgarni Archidiecezjalnej 2009.

Greshake Gisbert: Wierzę w Boga trójjedynego. Klucz do zrozumienia Trójcy Świętej, thum. Wiesław Szymona, Kraków: Wydawnictwo Znak 2001.

\footnotetext{
${ }^{26}$ Tamże, s. $70 \mathrm{n}$.
} 
JAGODZIŃSKI Marek: Trialogiczno-komunijna koncepcja trynitologii, „Studia Diecezji Radomskiej” 10 (2010/2011), s. 59-72.

LISZKA Piotr: Duch Święty, który od Ojca (i Syna) pochodzi, Wrocław: Papieski Wydział Teologiczny 2000.

KASPER Walter: Bóg Jezusa Chrystusa, tłum. Jan Tyrawa, Wrocław: TUM Wydawnictwo Wrocławskiej Księgarni Archidiecezjalnej 1996.

LAurentin René: Nieznany Duch Święty. Odkrywanie Jego doświadczenia i Jego Osoby, tłum. Maria Tarnowska, Kraków: Wydawnictwo Znak 1998.

StubenRauch Bertram: Pneumatologia - traktat o Duchu Świętym, (Podręcznik Teologii Dogmatycznej, red. Wolfgang Beinert, traktat VIII), tłum. Piotr Lisak, Kraków: Wydawnictwo „M” 1999

\section{KOMUNIJNO-TRYNITARNA POZYCJA DUCHA ŚWIĘTEGO}

\section{Streszczenie}

W Nowym Testamencie można zauważyć początki pneumatologii trynitarnej, która zaczęła się rozwijać w zmieniającym się kontekście świata kulturowego. Istotne znaczenie miało tu spojrzenie na Ducha Świętego w perspektywie miłości trynitarnej. Komunijny wymiar miało także nauczania o Filioque. Od średniowiecza rozpoczął się na Zachodzie pewien proces zapominania o Duchu Świętym i dopiero w nowszej teologii nastąpił w pneumatologii renesans, możliwy dzięki zintegrowaniu refleksji teologicznej i doświadczenia duchowego, w szczególności dzięki nowemu obudzeniu się w Kościele poczucia zjednoczenia na sposób komunii, które ośmieliło wybitnych teologów do podejmowania wnikliwych poszukiwań pneumatologicznych.

Słowa kluczowe: pneumatologia; Trójca Święta; Komunia; Filioque; kenoza. 